\title{
Defoliation of common ragweed by Ophraella communa beetle does not affect pollen allergenicity in controlled conditions
}

\author{
S. T. E. LOMMEN ${ }^{1, \star}$, S. CIAPPETTA ${ }^{2, \star}$, A. GHIANI ${ }^{2}$, R. ASERO ${ }^{3}$, R. GENTILI ${ }^{2}$, \\ H. MÜLLER-SCHÄRER ${ }^{1}, \&$ S. CITTERIO ${ }^{2}$ \\ ${ }^{1}$ Departement de Biologie/Ecologie Ev Evolution, Université de Fribourg, Switzerland; ${ }^{2}$ Department of Earth and Environmental \\ Sciences, Università di Milano-Bicocca, Italy and ${ }^{3}$ Ambulatorio di Allergologia, Clinica San Carlo, Italy
}

\begin{abstract}
Ragweed allergy is one of the primary causes of seasonal allergies in Europe and its prevalence is expected to rise. The leaf beetle Ophraella communa, recently and accidentally established in N-Italy and S-Switzerland, represents a promising approach to control ragweed, but negative side effects should be excluded before its use. Since biotic and abiotic stresses are known to influence the allergenicity of pollen, we set out to assess the effect of sub-lethal defoliation by $O$. communa on the quantity and quality of ragweed pollen. Seventeen sister pairs (including six clones) of ragweed plants were grown in controlled conditions. One of each pair was exposed to O. communa as soon as the plant started to produce reproductive structures. After 10 weeks of exposure, plant traits were measured as a proxy for pollen quantity. Pollen quality was assessed by measuring its viability and allergenicity. Generally, plants produced very few male flowers and little amount of pollen. Damage by the beetle was severe with most of the leaf tissue removed, but no treatment effect was found on any of the quantitative and qualitative traits assessed. In conclusion, O. communa did not increase the amount or allergenicity of ragweed pollen grains in our experimental conditions.
\end{abstract}

Keywords: Ambrosia artemisiifolia, common ragweed, pollen, allergenicity, Ophraella communa, biological control

\section{Introduction}

Ambrosia artemisiifolia L. (common ragweed), a North America native plant, has been accidentally introduced to Europe where it has naturalized since the 19 th century. It represents an increasingly serious threat to both environment and human health. The high ability of adaptation, reproduction, and dispersal make this plant a good competitor in disturbed areas affecting the existing plant diversity (Fenesi \& Botta-Dukát 2012). Ambrosia artemisiifolia also has become a major weed in European agriculture, especially in spring-sown crops such as sunflower, maize, sugar beet, and soybean (Komives et al. 2006). In addition, $A$. artemiisifolia produces large quantities of highly allergenic pollen representing one of the main causes of pollinosis in many regions of the word (Smith et al. 2013). In Europe, given the high prevalence of sensitized people, social and economic impacts are significant (D'Amato et al. 2015). For instance, the annual health costs related to ragweed allergy have been estimated at $€ 110$ million in Hungary, $€ 88$ million in Austria (Gerber et al. 2011, and references therein) and more than $€ 1.7$ million in a $90 \mathrm{~km}^{2}$ area in North Italy (http://www.aslmil. mi.it/), areas all highly invaded by $A$. artemiisifolia.

Common ragweed is continuing to expand across Europe, and future changes in climate and land use are expected to facilitate further spread to currently unsuitable areas (Essl et al. 2015). These changes can also augment the production of pollen (Ziska \& Caulfield 2000; Singer et al. 2005). Hamaoui-Laguel et al. (2015) predicted a fourfold increase in airborne concentration of common ragweed pollen in Europe by 2050 . This great increase in pollen concentration in the atmosphere along with the presence of pollutants, which can increase the allergenic potential of pollen (Zhao et al. 2016), constitutes a further alarming threat to human health.

Current management of $A$. artemisiifolia is mainly based on the use of broad-spectrum herbicides and mowing (Bohren et al. 2006; Patracchini et al. 2011), the latter of which has been enforcedly adopted by several local health authorities and municipalities to reduce pollen production, but effects are limited so far (Müller-Schärer et al. 2014). Another promising approach is classical biological control, where

Correspondence: S. Citterio, Dipartimento di Science Ambientali, Università di Milano-Bicocca, Piazza della Scienza 1, Milano 20126 , Italy. Tel: +39 02 64482934. Fax: +3902 64482996. Email: sandra.citterio@unimib.it

^These authors are contributed equally to this work. 
natural enemies from the native range are introduced to control the plant in the invaded range (MüllerSchärer \& Schaffner 2008). This method has proven to be permanent, environmentally friendly and a cost-effective control of several invasive plants (Seastedt 2015). In 2013, the leaf beetle Ophraella communa LaSage (Coleoptera: Chrysomelidae), already used as a biocontrol agent of ragweed in China (Zhou et al. 2011) and also effective against ragweed in Australia (Palmer et al. 2010), was unexpectedly found to have established in Northwestern Italy and southern Switzerland (Boriani et al. 2013; Müller-Schärer et al. 2014). The insect preferentially feeds on $A$. artemisiifolia, and severe defoliation can result in a reduction of flower and seed production, or can even kill the plant before flowering (Zhou et al. 2014). During the summer 2013 and 2014, concentrations of airborne ragweed pollen were significantly lower near the center of the colonized Italian area than what would be expected based on meteorological data of the region (Bonini et al. 2015). This strongly indicates a huge effect of the insect, and a direct benefit for human health. Nevertheless, before deciding on actively spreading this insect for ragweed control, potential concomitant negative impacts for human health, agriculture and the environment need to be carefully studied. Regarding human health, it is yet unclear how sublethal damage by O. communa will affect the quantity and quality of ragweed pollen produced. Non-lethal attack by aphids under controlled conditions reduced not only the quantity but also the viability and protein quantity of $A$. artemisiifolia pollen (Basky \& Magyar 2009). However, a body of literature shows opposite effects, with several types of biotic and abiotic environmental stress increasing the severity and frequency of respiratory allergic diseases (Singer et al. 2005; Smith et al. 2013; Sinha et al. 2014; Zhao et al. 2015). Consequently, it cannot be excluded that non-lethal attack levels by $O$. communa may result in more aggressive (more allergenic) pollen.

In this paper, we report results of a laboratory experiment investigating the impact of defoliation by $O$. communa during flowering time on the quantity, viability, and allergenicity of pollen produced by common ragweed plants.

\section{Materials and methods}

\section{Plant material}

Both plants grown from seeds of single mother plants and clonal plants were used to test the effect of $O$. communa on ragweed. Seeds were collected from a ragweed population grown in the Botticino extraction basin (Brescia, Italy), an area not invaded by $O$. communa, in October 2009, and stored in paper bags at room temperature. In Spring 2015 they were cold-stratified in the dark at $4^{\circ} \mathrm{C}$ for 3 months, and then planted in a tray. Single seedlings of $20 \mathrm{~mm}$ long were transferred to plastic pots $(14 \mathrm{~cm}$ diameter $\times 14 \mathrm{~cm}$ height) and grown in controlled condition (temperature: $25^{\circ} \mathrm{C} ; 10 \mathrm{~h}$ dark $/ 14 \mathrm{~h}$ light, $150 \mu \mathrm{mol} \mathrm{m} \mathrm{m}^{-2}$; humidity: $65 \%$ ).

Some of the obtained plants were vegetatively propagated to produce clonal individuals. To this purpose plant shoots were cut into nodal segments with one leaf and one lateral bud. The nodal segments were then cultivated in tubes containing $5 \mathrm{~mL}$ of MS medium supplied with Gambourg (B5) vitamins and supplemented with 4,5 $\mu \mathrm{M}$ 6-benzylaminopurine (BAP) to induce shoots regeneration. After 30 days of cultivation, microshoots $>2-3 \mathrm{~cm}$ with three or more leaves were excised and cultured on MS medium plus Vitamin B5 containing 0,5 $\mu \mathrm{M}$ indole-3-acetic acid (IAA) for rooting and growth. Finally, rooted plants were transplanted to pots and growth along with the plant from seeds in controlled conditions as described above.

\section{Ophraella communa}

Egg batches and males of Ophraella communa were collected from $A$. artemisiifolia in Magnagno, ca. $40 \mathrm{~km}$ from Milano, on two occasions in July 2015. They were kept in aerated pots, provided with ample fresh leaves of $A$. artemisiifolia in the same room as the plants for a maximum of 10 days.

\section{Experimental procedure}

Plants were weekly checked for the presence of floral buds. Once the first buds appeared in July 2015, a total of 17 pairs of plants were formed, by choosing 11 pairs of sister plants (all from different mother plants) and 6 pairs of relative clones (from 6 individual plants) that were as uniformly in size as possible. Of each pair, one was randomly assigned to the beetle treatment, and the other served as control. Individual plants were subjected to their assigned treatment when their floral buds appeared, and all treatments started within a three-week period. The maximum height and width of the plants were measured as an indication of size. Plants were then caged with partially transparent insect-free white tissue, from the pot until just below the first inflorescence, where the tissue was carefully attached to a sponge that surrounded the stem of the plant to protect it (Figure 1(A)). Plants assigned to the Ophraella treatment received a centrifuge tube near their stem before the tissue was closed, and which contained six male beetles and three unhatched egg batches each containing a minimum of 10 eggs on pieces of leaves, 

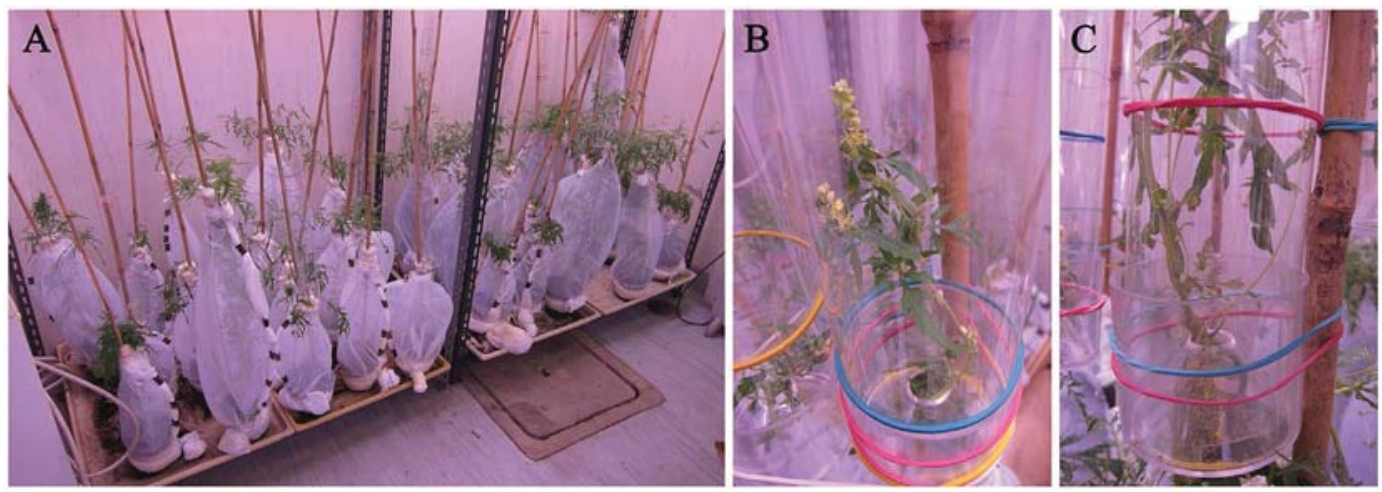

Figure 1. (A) Control and exposed plants caged with partially transparent insect-free white tissue. (B, C) Male inflorescences covered with transparent collectors (modified ARACON system) used to recover mature pollen.

collected 1-10 days before. In two cases where no beetles or larvae were seen after a week, the same amount of beetles was added again. In addition, we applied a cutting treatment to the uncaged leaves of all Ophraella-treated plants to simulate Ophraella feeding of those leaves that could not be accessed by Ophraella. Three weeks after the start of the treatment, $90 \%$ of the uncaged leaf tissue was cut manually in such a manner that only the veins remained, and this was repeated biweekly. When the caged part of the plant had been completely defoliated by the beetles (usually after four weeks), all remaining beetles were removed by an exhauster. Control plants were caged similarly but did not receive any beetles nor manual cutting. Mature pollen of each plant was recovered in transparent collectors, by covering 1-3 male inflorescences with a modified ARACON system (Kanter et al. 2013; Figure 1(B)) until 10 weeks after the start of the treatments.

\section{Plant traits}

We collected data on plant performance that are known to be well related with the amount of pollen produced (Fumanal et al. 2007; Šauliene et al. 2012). Plant height (cm), measured from the ground to the maximum growing point of the main branch, and lateral spread $(\mathrm{cm})$, measured as the maximum diameter of the plant, were recorded just before the cage was installed and after 10 weeks of treatment. In addition, the following plant reproductive traits were recorded per plant: the number of racemes (the spikes with male flower heads), male flower heads, and female flowers, as well as the weight of the pollen collected.

\section{Pollen viability}

Membrane integrity and viability of pollen grains were estimated using the fluorescein diacetate (FDA) method (Heslop-Harrison \& Heslop-Harrison 1970). This is based on the incubation of $0.1 \mathrm{mg}$ of pollen with $1 \mathrm{ml}$ of Mannitolo-FDA solution (0.3 M Mannitol and $0.01 \mathrm{mg} \mathrm{mL}^{-1} \mathrm{FDA}$ ) for $15 \mathrm{~min}$ in darkness at room temperature. The percentage of viable grains was estimated for single raceme by counting in a Bürker chamber using a standard fluorescence microscope (400× magnification) equipped with epi-illumination (Axioplan, Zeiss, Germany), $100 \mathrm{~W}$ halogen bulb, band pass $450-490 \mathrm{~nm}$ (blue) excitation filter, $510 \mathrm{~nm}$ chromatic bean splitter, and $520 \mathrm{~nm}$ long-pass filter. A pollen grain was considered as viable, when it emitted green fluorescence under blue excitation. Three independent experiments for each raceme were performed.

\section{Pollen allergenicity}

Slot blot technique was applied to assess the whole allergenicity of pollen collected from the different racemes. Soluble protein extracts were prepared according to Aina et al. (2010). Equal volumes of these extracts were bound to nitrocellulose membrane and first stained with Ponceau S staining solution $[0.1 \%(\mathrm{w} / \mathrm{v})$ Ponceau $\mathrm{S}$ in $5 \%(\mathrm{v} / \mathrm{v})$ acetic acid] to assess the amount of proteins loaded in each well. Membranes were then used to evaluate the immunoreactivity of the different pollen extracts to a pool of sera from ragweed allergic patients, previously selected (Asero et al. 2014). Image analysis was applied to quantify reactivity signals. The integrated optical density (IOD) of immunoreactive spots with respect to the IOD of standard (Allergon ${ }^{\circledR}$ ) was measured. At least three different samples for each racemes were analyzed.

\section{Statistical analysis}

Statistical analyses were performed using the GraphPad Prism software for Windows (version 4.0 
Table I. Mean \pm standard error (SE) of the principal traits measured in beetle exposed and not-exposed (control) plants at the end of the experiment. No effect of the Ophraella treatment was found on any of the plant traits measured (ANOVA and Tukey's test or Kruskal-Wallis $p>0.05$ ).

\begin{tabular}{lcccc}
\hline Plant traits & $N$ & $\begin{array}{c}\text { Control } \\
\text { (mean } \pm \text { SE) }\end{array}$ & $N$ & $\begin{array}{c}\text { Exposed } \\
\text { (mean } \pm \text { SE) }\end{array}$ \\
\hline $\begin{array}{l}\text { Plant height } \\
(\mathrm{cm})\end{array}$ & 17 & $42.71 \pm 4.44$ & 14 & $45.29 \pm 3.55$ \\
$\begin{array}{l}\text { Plant width } \\
(\mathrm{cm})\end{array}$ & 17 & $30.35 \pm 4.26$ & 14 & $26.50 \pm 2.41$ \\
$\begin{array}{l}\text { No of female } \\
\text { flowers per } \\
\text { plant }\end{array}$ & 17 & $697.71 \pm 237.29$ & 14 & $219.93 \pm 44.26$ \\
$\begin{array}{l}\text { No of male } \\
\text { racemes per } \\
\text { plant }\end{array}$ & 9 & $1.44 \pm 0.13$ & 8 & $1.75 \pm 0.31$ \\
$\begin{array}{l}\text { No of male } \\
\text { heads per plant }\end{array}$ & 9 & $32.75 \pm 10.86$ & 8 & $28.00 \pm 8.85$ \\
$\begin{array}{l}\text { Pollen weight } \\
\text { per plant (mg) }\end{array}$ & 6 & $2.68 \pm 1.35$ & 5 & $1.22 \pm 0.28$ \\
\hline
\end{tabular}

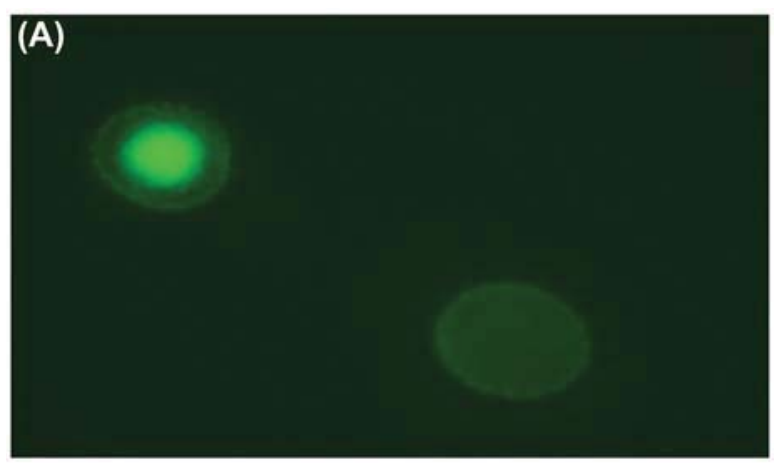

(B)

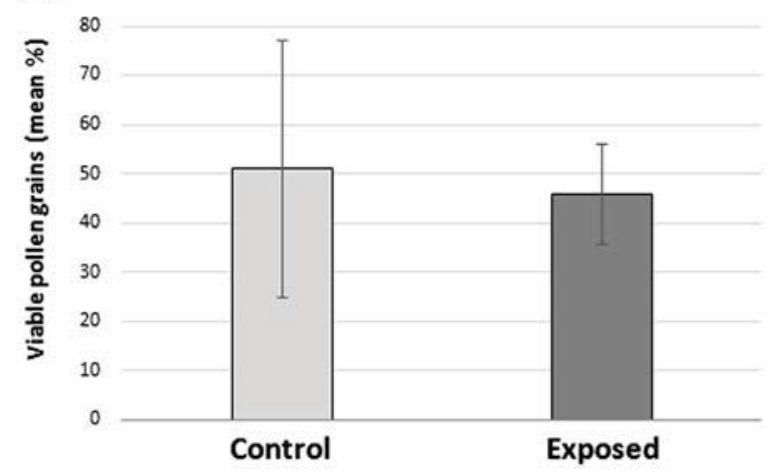

Figure 2. Viability of mature ragweed pollen released from flowers. (A) Staining with FDA: viable pollen grains show bright fluorescence; (B) mean percentage of viable pollen grains in control and $O$. communa exposed plants. No statistical difference between control and exposed plants was found, according to the Kruskal-Wallis non-parametric procedure $(p>0.05)$.

GraphPad Software Inc., San Diego CA): ANOVA and Tukey test were applied to the data when normality and homogeneity of variance were satisfied. Data not conforming to the assumptions (pollen viability, no of female flowers and racemes and pollen weight per plant) were log-transformed or analyzed by Kruskal-Wallis non-parametric procedure.

\section{Results}

Ragweed clones and plants from seeds were exposed to the beetle since the very beginning of their flower development for 10 weeks, whereas a sister plant/ clone remained untreated. After this period, plant traits as a proxy for pollen production, along with the pollen viability and allergenicity were measured.

Ophraella feeding both by adults and larvae caused complete defoliation in the treatment cages and all but three plants (all from the Ophraella treatment) survived. In addition, we observed some damage by thrips on dried leaves on most of the treated and control plants. Remarkably, all plants produced predominantly female flowers, and only few male flowers. Half of all plants produced racemes, and sufficient amounts of pollen for quantitative analyses were collected from 6 controls (including two clones) and 5 Ophraella-treated plants (including 1 clone identical to one of the two control clones) before the end of the experiment. No effect of the Ophraella treatment was found on any of the plant traits measured at the end of the experiment (Table I). Also the clone pairs did not show any statistical difference $(p>0.05)$. Pollen viability determined by FDA staining (Figure 2(A)) was about $50 \%$ in both exposed and control plants (Figure 2(B)), and no effect of the beetle was found.

Total pollen allergenicity was assessed by slot blot technique. Figure 3(A) shows a representative membrane after immunodetection with a pool of sera from selected ragweed allergic patients. Image analysis was applied to quantify immunochemical signals: the IOD of immunoreactive spots with respect to the IOD of standard (sample IOD/standard IOD) was measured. On average, the reactivity signal of pollen samples from plants exposed to O. communa ranged from 0.97 to 1.04 whereas that of control plants ranged from 1.00 to 1.04 (relative units; Figure $3(\mathrm{~B}))$. The mean values between treated and control plants were not statistically different $(p>0.05)$, indicating no effect of O. communa.

\section{Discussion}

Pollen allergenicity is widely recognized as a major determinant of health effects for sensitized patients, in addition to temporal and spatial allergen exposure (Cecchi et al. 2010). The allergenic potency of pollen, which is species specific, can be modulated by environmental conditions; many biotic and abiotic environmental stresses such as micro-organism infections (Won Jung et al. 2003), increased 

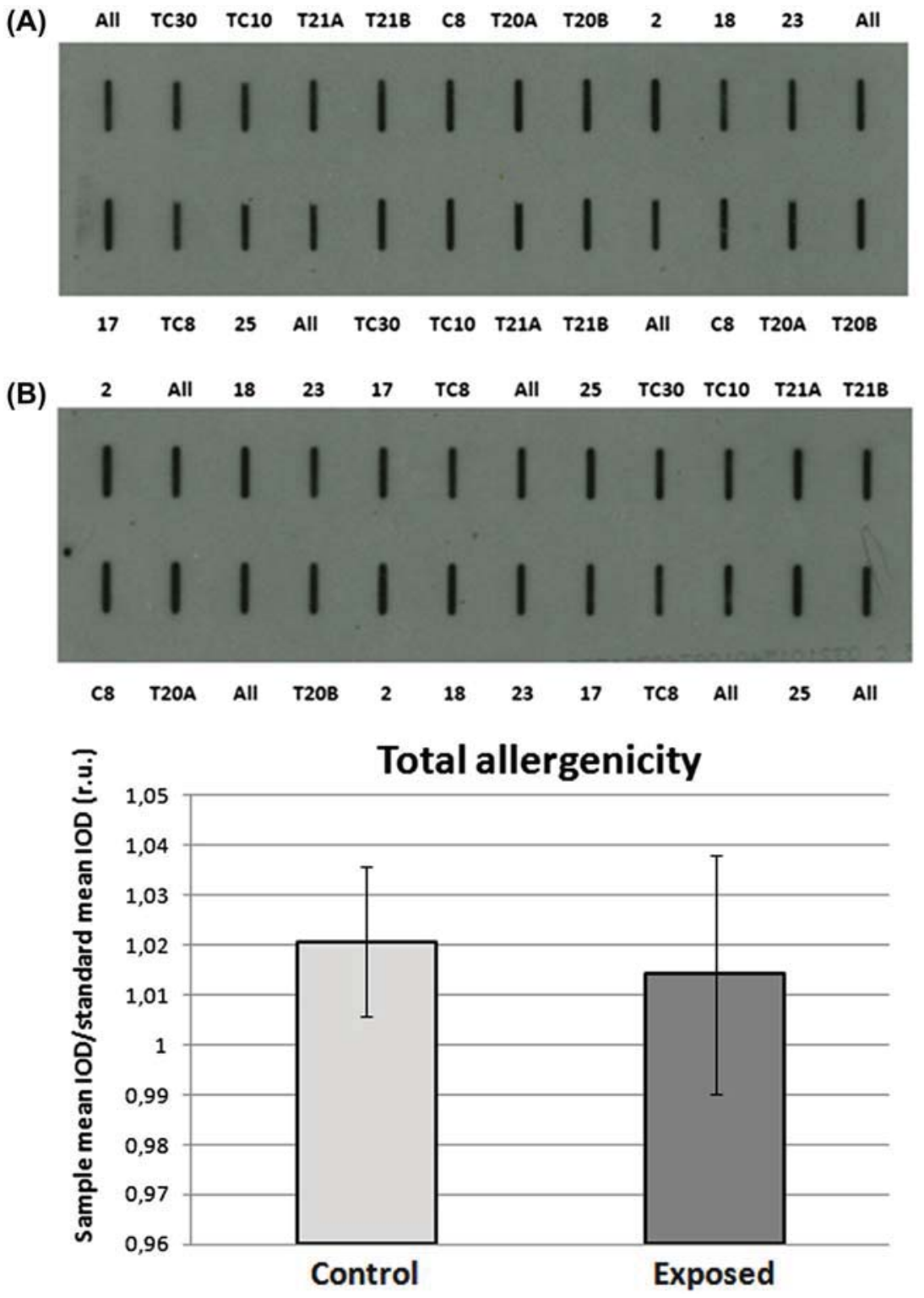

Figure 3. Total allergenicity of pollen samples from single racemes assessed with slot blotting. (A) Representative slot blot membrane probed with a pool of selected patient sera; All: internal standard (commercial pollen from Allergome). (B) Assessment of total pollen allergenicity through image analysis: the IOD of immunoreactive sposts with respect to the IOD of the standard (field sample IOD standard IOD), was measured. The results reported are the mean ( \pm standard deviation) of three independent experiments. ANOVA and Tukey test, $p>0.05$ were performed; r.u.: relative units.

atmospheric greenhouse gasses, temperature, and air pollution (Shea et al. 2008; Smith et al. 2013), can in fact increase pollen allergenicity and consequently the severity and frequency of respiratory allergic diseases (D'Amato et al. 2015).

Pathogen attacks and insect feeding, in particular, trigger the expression of plant defensive proteins that exert direct effects on the antagonist or play a protective role for plant organs. Some of these proteins are allergens, which are accumulated in plant tissues. Examples are LTP allergens, which are proven to be transcriptionally activated by pathogen infection in Capsicum annuиm tissues, and some classes of pathogenesis-related proteins (PRPs; Datta \& Muthukrishnan 1999; Hoffmann-Sommergruber et al. 2000; Sinha et al. 2014). Thus, although the recent and accidental introduction of $O$. communa to Northern Italy represents a great opportunity to control $A$. artemisiifolia, the attacks by this insect also represents stress, and may therefore increase the amount or allergenicity of ragweed pollen in surviving plants. This may be problematic when these insects are used for biological control of the plants canceling its positive biocontrol effect on human health.

In our experiment, attack by $O$. communa and additional manual defoliation during flowering did 
not alter the amount or allergenic potential of pollen from ragweed plants. Unfortunately no data concerning the effect of insect feeding or mechanical defoliation on fruit and pollen allergenicity have been carried out to date. Very few data are also available from experiments with viruses. Welter et al. (2013), for instance, found no effect of pepino mosaic virus infection on the allergenic potential of tomato fruits. This lack of effect is in line with our results and can be explained by taking into account the plant's ability and competence to respond to damage and the type of defense response. It is possible that O. communa induces the synthesis of non-allergenic defense compounds or activates a local, but not a systemic response and/or that the ability of ragweed defense response is restricted to specific development stages. A meta-analysis that summarized ontogenetic patterns in plant defense traits illustrated that, in the case of herbaceous plants, the ability to induce defenses (including secondary metabolites and proteins) after damage usually decreased with plant age. (Barton \& Koricheva 2010). For instance, Quintero and Bowers (2011), showed that the ability of the annual plant Plantago lanceolata to induce chemical defenses against Funonia coenia was limited to juvenile, but not present in mature plant stages. Consequently, also common ragweed may preferentially synthetize defense proteins before flowering. In addition, it cannot be excluded that insect attack under field condition may induce a different plant reaction. Plants often have to cope with multiple attacks and belong to a population with genetically diverse individuals, which are not attacked at the same time and interact each other by exchanging signals. All these factors along with additional unpredictable surrounding environmental conditions modulate the complex regulation network of the plant's defense system influencing the expression of defense proteins including allergens. Furthermore, it should be taken into account that the effect of single biotic factors may be too weak to cause stable changes in the allergenicity of mature pollen and thus difficult to be observed by experiments in controlled conditions. Finally, the application of a cage around our plants and additional unintended infections may have affected our results. After caging, all the plants in the experiment grew slower, produced relatively large amounts of female flowers and very few male inflorescences, compared to the unused plants left uncaged (data not shown). Because stress due to the conditions, caging and unintended infections occurred in both exposed and control plants, it was still possible to assess the additional effect of the heavy stress of the defoliation treatment. In our experimental conditions, allergenicity of pollen was unaffected by the caging and infections, since there was no difference with unused plants left uncaged (ANOVA and Tukey test, $p>0.05$ ) indicating that defoliation of mature $A$. artemisiifolia may indeed not affect allergenicity.

This study represents a first attempt to define the effect of $O$. communa on ragweed pollen amounts and allergenicity. More extended studies in controlled and field conditions are presently underway.

\section{Acknowledgements}

The authors thank Alessandro Crippa, Mattia Di Maggio, Sanela Milenkovic, Aleksandra Krsmanovic and Aleksandra Savić for assisting in setting up the experiment and data collection. We thank Joelle Romanens and Benno Augustinus for providing material and transportation.

\section{Funding}

This work was supported by the Italian Ministry of Education University and Research under [grant number 2014-ATE-0387]; the Federal Office for the Environment under [grant number 13.0098. KP/M323-0760]; the Federal Office for Agriculture under [grant number 1062-62200]; the Swiss State Secretariat for Education, Research and Innovation under [grand number C13.0146] to HMS; and the EU COST Action FA1203 "Sustainable management of Ambrosia artemisiifolia in Europe (SMARTER).”

\section{References}

Aina R, Asero R, Ghiani A, Marconi G, Albertini E, Citterio S. 2010. Exposure to cadmium-contaminated soils increases allergenicity of Poa annua L. pollen. Allergy 65(10): 13131321.

Asero R, Bellotto E, Ghiani A, Aina R, Villalta D, Citterio S. 2014. Concomitant sensitization to ragweed and mugwort pollen: Who is who in clinical allergy? Ann Allergy Asthma Immunol 113: 307-313.

Barton KE, Koricheva J. 2010. The ontogeny of plant defense and herbivory: Characterizing general patterns using metaanalysis. Am Nat 175(4): 481-493.

Basky Z, Magyar D. 2009. Impact of indigenous aphids on development of the invasive common ragweed (Ambrosia artemisiifolia L.) in Hungary. J Pest Sci 82(1): 19-25.

Bohren C, Mermillod G, Delabays N. 2006. Common ragweed (Ambrosia artemisiifolia L.) in Switzerland: Development of a nationwide concerted action. Zeitschrift fur Pflanzenkrankheiten und Pflanzenschutz-Sonderheft 20: 497-503.

Bonini M, Sikoparija B, Prentovic M, Cislaghi G, Colombo P, Testoni C, et al. 2015. A follow-up study examining airborne Ambrosia pollen in the Milan area in 2014 in relation to the accidental introduction of the ragweed leaf beetle Ophraella communa. Aerobiologia 32. doi: 10.1007/s10453-015-9406-2.

Boriani M, Calvi M, Taddei A, Tantardini A, Cavagna B, Andreani F, et al. 2013. Ophraella communa segnalata in Italia su Ambrosia. L'Informatore Agrario 34: 2-3.

Cecchi L, D'Amato G, Ayres JG, Galan C, Forastiere F, Forsberg B, et al. 2010. Projections of the effects of climate change on allergic asthma: The contribution of aerobiology. Allergy 65(9): 1073-1081. 
D'Amato G, Holgate ST, Pawankar R, Ledford DK, Cecchi L, Al-Ahmad M, et al. 2015. Meteorological conditions, climate change, new emerging factors, and asthma and related allergic disorders. A statement of the World Allergy Organization. World Allergy Organ J 8(1): 1-52.

Datta SK, Muthukrishnan S, editors. 1999. Pathogenesis-related proteins in plants. Boca Raton, FL: CRC Press.

Essl F, Dullinger S, Rabitsch W, Hulme PE, Pyšek P, Wilson JRU, et al. 2015. Delayed biodiversity change: No time to waste. Trends Ecol Evol 30: 375-378. doi:10.1016/j. tree.2015.05.002.

Fenesi A, Botta-Dukát Z. 2012. Phenotypic divergences induced by different residence time in invasive common ragweeds. J Plant Ecol 5: 174-181.

Fumanal B, Chauvel B, Bretagnolle F. 2007. Estimation of pollen and seed production of common ragweed in France. Ann Agric Environ Med 14: 233-236.

Gerber E, Schaffner U, Gassmann A, Seier M, Müller-Schärer H. 2011. Prospects for biological control of Ambrosia artemisiifolia in Europe: Learning from the past. Weed Res 51: 559-573.

Hoffmann-Sommergruber K. 2000. Plant allergens and pathogenesis-related proteins. Int Arch Allergy Immunol 122(3): 155-166.

Kanter U, Heller W, Durner J, Winkler JB, Engel M, Behrendt H, et al. 2013. Molecular and immunological characterization of ragweed (Ambrosia artemisiifolia L.) pollen after exposure of the plants to elevated ozone over a whole growing season. PloS One 8(4): e61518.

Komives T, Béres I, Reisinger P, Lehoczky E, Berke J, Tamás J, et al. 2006. New strategy of the integrated protection against common ragweed (Ambrosia artemisiifolia L.). Hung Weed Res Technol 6: 5-50.

Hamaoui-Laguel L, Vautard R, Liu L, Solmon F, Viovy N, Khvorostyanov D, et al. 2015. Effects of climate change and seed dispersal on airborne ragweed pollen loads in Europe. Nat Clim Change 5: 766-771.

Heslop-Harrison J, Heslop-Harrison Y. 1970. Evaluation of pollen viability by enzymatically induced fluorescence; intracellular hydrolysis of fluorescein diacetate. Biotech Histochem 45(3): 115-120. doi:10.3109/10520297009085351.

Müller-Schärer H, Schaffner U. 2008. Classical biological control: Exploiting enemy escape to manage plant invasions. Biol Invasion 10: 859-874.

Müller-Schärer H, Lommen ST, Rossinelli M, Bonini M, Boriani M, Bosio G, et al. 2014. Ophraella communa, the ragweed leaf beetle, has successfully landed in Europe: Fortunate coincidence or threat? Weed Res 54(2): 109-119.

PalmerWA, Heard TA, Sheppard AW. 2010. A review of Australian classical biological control of weeds programs and research activities over the past 12 years. Biol Control 52: 271-287.

Patracchini C, Vidotto F, Ferrero A. 2011. Common ragweed (Ambrosia artemisiifolia) growth as affected by plant density and clipping. Weed Technol 25(2): 268-276.
Quintero C, Bowers MD. 2011. Plant induced defences depend more on plant age than previous history of damage: Implications for plant-herbivore interactions. J Chem Ecol 37(9): 992-1001.

Šaulienè I, Veriankaitè L, Šaulys A. 2012. Biometrical assessment of ragweed (Ambrosia artemisiifolia L.). Žemdirbystè Agric 99(3): 319-326. ISSN 1392-3196.

Seastedt TR. 2015. Biological control of invasive plant species: A reassessment for the Anthropocene. New Phytol 205: 490-502.

Singer BD, Ziska LH, Frenz DA, Gebhard DE, Straka JG. 2005. Research note: Increasing Amb a 1 content in common ragweed (Ambrosia artemisiifolia) pollen as a function of rising atmospheric $\mathrm{CO}_{2}$ concentration. Funct Plant Biol 32(7): 667670.

Sinha M, Singh RP, Kushwaha GS, Iqbal N, Singh A, Kaushik S, et al. 2014. Current overview of allergens of plant pathogenesis related protein families. Sci World J 2014: 19. Available: http:// dx.doi.org/10.1155/2014/543195

Shea KM, Truckner RT, Weber RW, Peden DB. 2008. Climate change and allergic disease. J Allergy Clin Immunol 122(3): 443-453.

Smith M, Cecchi L, Skjøth CA, Karrer G, Šikoparija B. 2013. Common ragweed: A threat to environmental health in Europe. Environ Int 61: 115-126.

Welter S, Dölle S, Lehmann K, Schwarz D, Weckwerth W, Worm M, et al. 2013. Pepino mosaic virus infection of tomato affects allergen expression, but not the allergenic potential of fruits. PloS One 8(6): e65116.

Won Jung H, Kim W, Hwang BK. 2003. Three pathogeninducible genes encoding lipid transfer protein from pepper are differentially activated by pathogens, abiotic, and environmental stresses. Plant Cell Environ 26(6): 915-928.

Ziska LH, Caulfield FA. 2000. Rising $\mathrm{CO}_{2}$ and pollen production of common ragweed (Ambrosia artemisiifolia), a known allergyinducing species: Implications for public health. Aust J Plant Physiol 27: 893-898.

Zhao F, Elkelish A, Durner J, Lindermayr C, Winkler JB, Ruëff F, et al. 2016. Common ragweed (Ambrosia artemisiifolia L.): Allergenicity and molecular characterization of pollen after plant exposure to elevated $\mathrm{NO}_{2}$. Plant Cell Environ 39(1): $147-164$.

Zhou ZS, Chen HS, Zheng XW, Guo JY, Wan FH. 2011. Combined control of common ragweed, Ambrosia artemisiifolia with Ophraella communa and Epiblema strenuana in Laibin, Guangxi Province, China. J Biosafety 20: 267-269.

Zhou ZS, Chen HS, Zheng XW, Guo JY, Guo W, Li M, et al. 2014. Control of the invasive weed Ambrosia artemisiifolia with Ophraella communa and Epiblema strenuana. Biocontrol Sci Technol 24: 950-964. 